\title{
Sand Distribution on the Inner Shelf South of Long Island, New York
}

Long Island, New York, contains deposits left about 20,000 years ago by late Pleistocene (ice age) glaciers at their southern limit in eastern North America (fig. 1). Long Island's south shore consists of reworked glacial sediment and includes shallow brackish-water lagoons and a low-relief barrier-island system. Coastal erosion along the barrier islands has received engineering, scientific, and political attention over the past few decades. Coastal communities, the local fishing industry, and tourism at the area's parks are all affected by coastal erosion.

In 1996, the U.S. Geological Survey and the U.S. Army Corps of Engineers began a program to map the geology of the sea floor along the south shore of Long Island by using a variety of remote-sensing techniques (including high-resolution sidescan-sonar imaging and subbottom profiling) supplemented by sediment sampling. Two main goals were (1) to investigate the roles that the inner shelf morphology and the geologic framework play in the evolution of this coastal region and (2) to assess sand-resource availability offshore for planned beach-nourishment projects.

\section{Geologic Framework}

The geologic framework of the inner shelf south of Long Island controls the evolution of the adjacent coastal system. Poorly lithified Cretaceous sedimentary strata more than 65 million years old are overlain by a relatively thin (typically less than 15 meters) blanket of glacial and modern sediment on the inner shelf. In places, such as offshore of Watch Hill, the Cretaceous strata crop out on the inner shelf (fig. 1).

Sea level has been rising for about 20,000 years. When sea level was lower, the Cretaceous outcrop formed the core

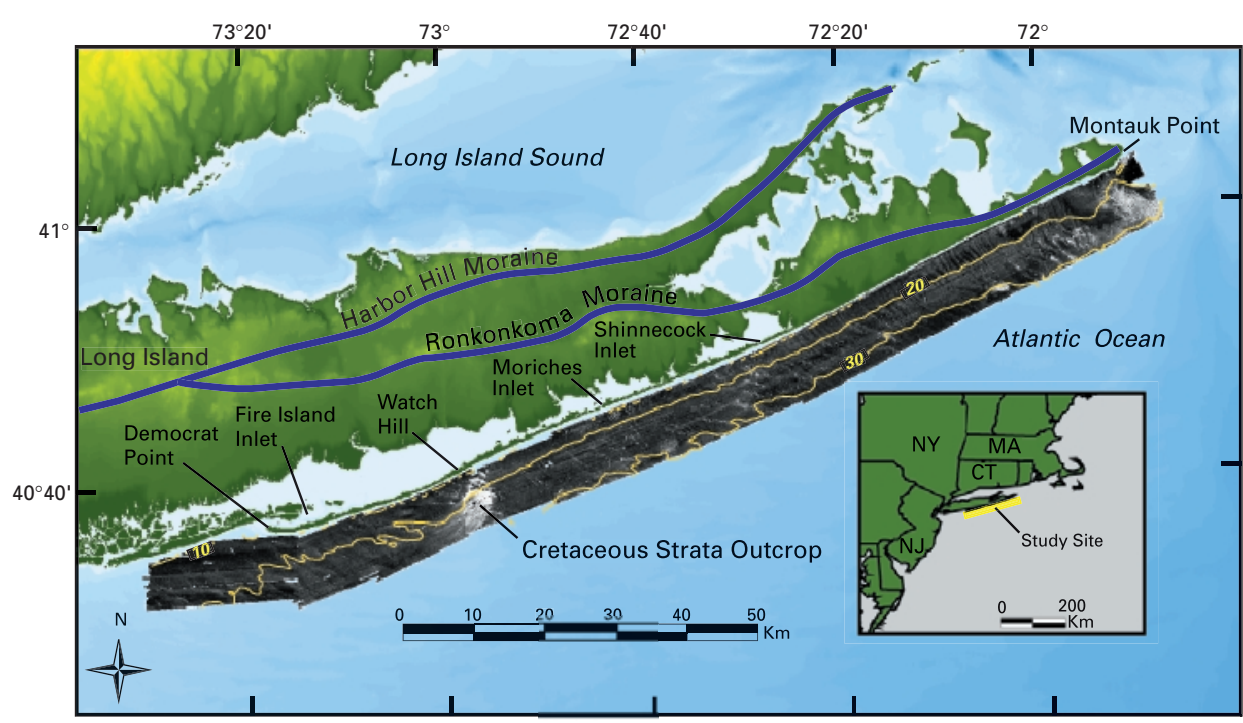

Figure 1. Sidescan-sonar imagery (black and white) of the inner shelf south of Long Island. Light tones indicate high backscatter (which correlates with sea-floor areas of coarse-grained sediment and a Cretaceous outcrop), and dark tones indicate low backscatter. The Harbor Hill and Ronkonkoma moraines represent the southernmost extent of late Pleistocene glaciation. Yellow contours show bathymetry in meters. The color variations above and below sea level show generalized relief modified from the National Geophysical Data Center's coastal relief model (http://www.ngdc.noaa.gov/mgg/coastal/coastal.html). of a coastal headland. Approximately 8,000 years ago, the rate of sea-level rise decreased, initiating the formation of the modern barriered coastal system about 18 meters below present sea level. As sea level continued to rise slowly, the barrier-island system migrated landward. Waves eroded the Cretaceous strata off Watch Hill, furnishing sand to the inner shelf that was transported downdrift to the west. The erosion of the inner shelf left a thin, patchy modern sandy sediment cover seaward of the barrier-island system (fig. 2).

The modern sand was reworked into a series of shoreface-attached ridges up to 5 meters thick where there was enough sand, such as west of the outcropping Cretaceous strata to Fire Island Inlet (fig. 2). Updrift (east) of the Cretaceous outcrop to Southampton, however, the modern sediment thickness is typically less than 2 meters, and glacial sediment is commonly exposed on the sea floor.

\section{Coastal Change}

Coastal-change studies based on historical maps of southern Long Island indicate that landward migration of the barrier-island system is slower where there is a lot of modern sediment on the adjacent inner shelf, such as west of Watch Hill to Fire Island Inlet (fig. $2)$. There have been no inlet breaches there in historic time; the barrier-island system has essentially remained in place and aggraded vertically.

In contrast, where modern sediment is thin on the inner shelf from the Cretaceous outcrop to Southampton, the barrier-island system has migrated rapidly but intermittently landward. Inlets were created at intervals of 50-75 years, and sand then accreted to the bay side of the island. 


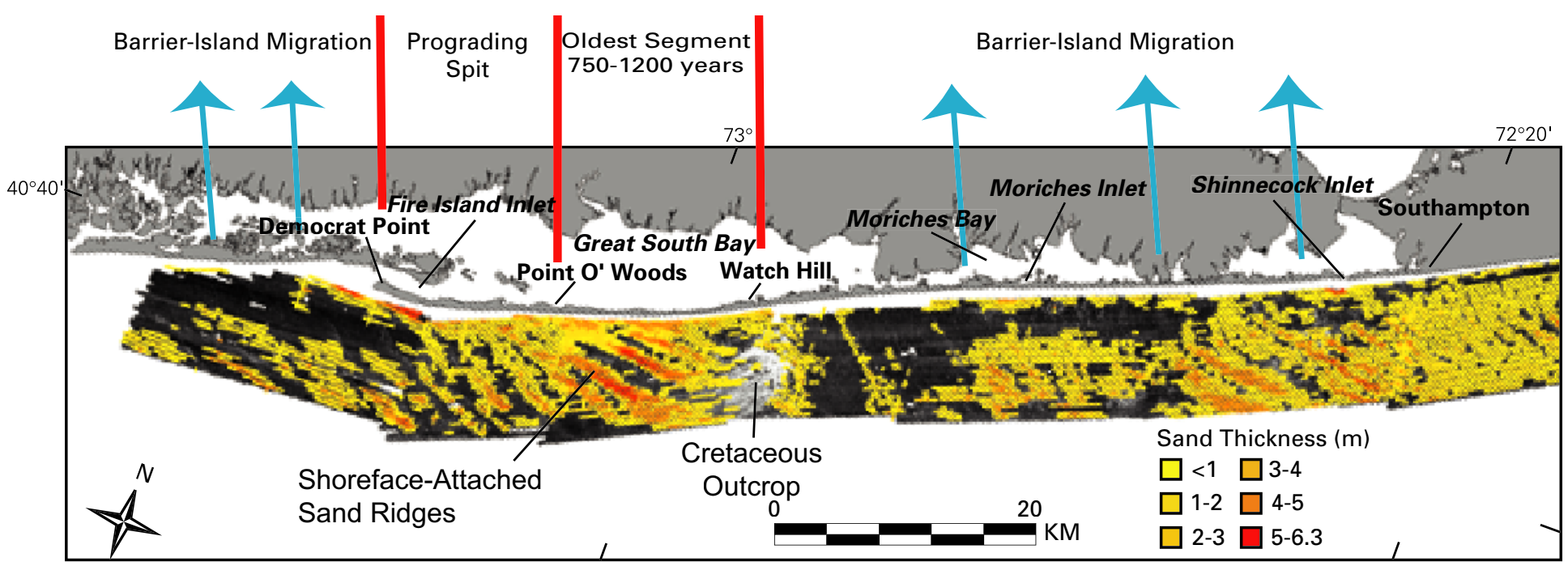

Figure 2. Sidescan-sonar imagery overlain with a map of modern sand thickness (in meters) of the inner shelf south of Long Island. The oldest most stable segment of the barrier-island system is immediately landward of the outcropping Cretaceous strata and thickest sand ridges. A westward and onshore sediment flux from these sand ridges probably supplies sediment to the beaches west of Watch Hill to Democrat Point. The barrier-island segment west of Point $0^{\prime}$ Woods formed as a prograding spit. Democrat Point accreted approximately
8 kilometers between 1825 and 1940, or about 69 meters per year. The sediment required to develop this spit far exceeds the estimated sediment volume being introduced from the east. Thus, the proposed sediment flux from the shoreface-attached sand ridges must introduce sufficient sediment to the coastal system for spit grow th. East and west of the shoreface-attached sand ridges, the barrier-island system has migrated rapidly but intermittently because of the creation of inlets and subsequent bayside accretion.

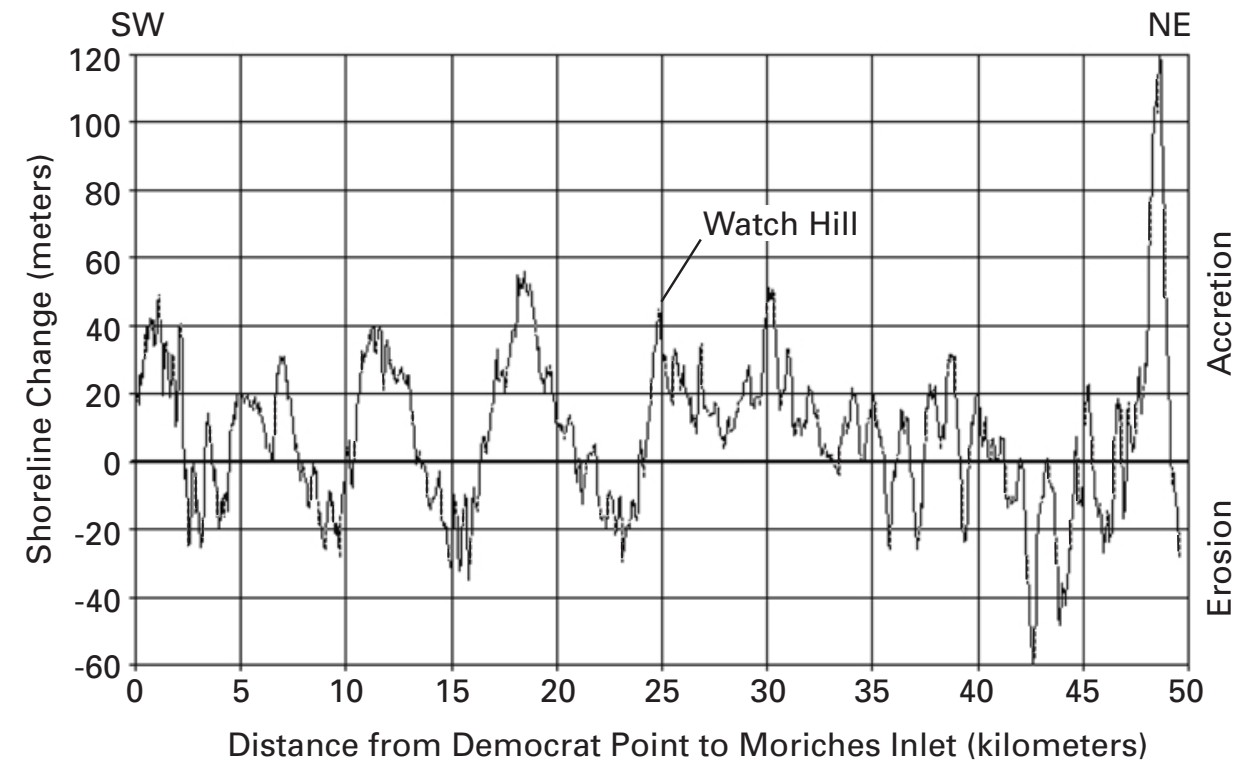

Figure 3. Shoreline-change trends between 1979 and 1994 on Fire Island. Distinct areas of erosion and accretion occur in a wavelike pattern west of Watch Hill, whereas the shoreline-change pattern east of Watch Hill is less clear. The differing patterns of recent shoreline behavior may be explained by (1) storm waves shoaling over the shoreface-attached sand ridges west of Watch Hill and focusing energy on certain segments of the coast, thereby causing erosion, and (2) interaction of the shoreface-attached sand ridges and a nearshore sand bar, allowing some segments of the bar to withstand storm waves more efficiently than adjacent segments.

\section{Offshore Sand Resource Potential}

Although the shoreface-attached sand ridges west of Watch Hill are a potential resource, there could be significant consequences for extracting sand from them, such as increased rates of coastal erosion landward and west of them. The ridges are thought to be a major source of sediment for the beach west of Watch Hill. Episodic erosion and accretion occur along discrete stretches of beach (fig. 3). Preliminary wave modeling suggests that the sand ridges focus wave energy and thereby control patterns of sediment transport and erosion along the barrier-island system.

For more information, please contact: William C. Schwab U.S. Geological Survey 384 Woods Hole Road Woods Hole, MA 02543-1598

Telephone: 508-457-2299

E-mail: bschwab@usgs.gov Web site: http://woodshole.er.usgs.gov/ 